\title{
Gene XRCC1Arg399GIn polymorphism and its genotype variations: clinical associations in Egyptian systemic lupus erythematosus patients
}

\author{
Mohamed A. Mortada ${ }^{1 *}$ (D, Haidy E. Zidan ${ }^{2}$, Noha A. Abdelsalam ${ }^{1}$ and Mirvat A. Eltoukhy ${ }^{1}$
}

\begin{abstract}
Background: Impaired deoxyribonucleic acid (DNA) repair may induce an autoimmune response in susceptible individuals. The association between DNA repair gene XRCC1 Arg399GIn gene polymorphism and susceptibility of systemic lupus erythematosus (SLE) is controversial. This study aimed to detect the association of XRCC1 Arg399GIn gene polymorphism with SLE and its clinical manifestations in the Egyptian population.

Results: A significant association was found between weight loss and genotype $G G(P=0.048)$; however, genotype AG was significantly associated with high serum creatinine and low C3 level $(P=0.039, P=0.009$, respectively). On the other hand, there was no significant difference between patients and controls regarding genotype and allele frequency.
\end{abstract}

Conclusions: An association was found between weight loss, high serum creatinine, and low C3 level and genotypes of XRCC1 Arg 399 Gln gene polymorphism.

Keywords: SLE, XRCC1Arg399GIn, Polymorphism, Alleles

\section{Background}

Systemic lupus erythematosus (SLE) is an autoimmune disease which is characterized by $\mathrm{T}$ and $\mathrm{B}$ cell hyperactivity, autoantibody production, activation of complement, and deposition of immune complex causing various clinical manifestations and intended tissue damage [1]. SLE presents with a wide spectrum of clinical and laboratory manifestations, during exacerbation and remission periods [2].

SLE incidence ranges from 20 to 150 patients per 100, 000 individuals, and its prevalence differs with genetic susceptibility, race, ethnicity, and socioeconomic factors [3]. It occurs more frequently in childbearing females with a female to male ratio of up to 13:1 [4].

\footnotetext{
* Correspondence: M_a_mortada@yahoo.com

${ }^{1}$ Rheumatology and Rehabilitation Department, Faculty of Medicine, Zagazig University, Zagazig, Egypt

Full list of author information is available at the end of the article
}

SLE pathogenesis is mainly because of the deficiency of multiple immunological mechanisms [5-7].

Deoxyribonucleic acid (DNA) is considered the most important autoantigen target for SLE autoantibodies, and the origin of these antibodies is uncertain [8]. Impaired DNA repair may induce an autoimmune response in susceptible individuals. DNA damage can be produced by endogenous factors involving reactive oxygen species, or indirectly during base excision repair (BER) pathway for DNA damage, or exogenous factors as chemicals, ionizing radiation, and ultraviolet (UV) irradiation [9].

Proteins encoded by the X-ray repair cross complementing (XRCC) gene families protect DNA against damage. Alterations in XRCC gene have been shown to be associated not only with SLE, but also with other autoimmune disorders due to its presence at DNA damage sites [10].

\section{Springer Open}

(-) The Author(s). 2020 Open Access This article is licensed under a Creative Commons Attribution 4.0 International License which permits use, sharing, adaptation, distribution and reproduction in any medium or format, as long as you give appropriate credit to the original author(s) and the source, provide a link to the Creative Commons licence, and indicate if changes were made. The images or other third party material in this article are included in the article's Creative Commons licence, unless indicated otherwise in a credit line to the material. If material is not included in the article's Creative Commons licence and your intended use is not permitted by statutory regulation or exceeds the permitted use, you will need to obtain permission directly from the copyright holder. To view a copy of this licence, visit http://creativecommons.org/licenses/by/4.0/. 
XRCC1 gene is located at chromosome 19 (19q13.2); it encodes 633 amino acid protein that acts as a scaffold to stabilize the BER proteins in both single-strand break repair and BER, being the most studied XRCC family member on SLE [11]. XRCC1 not only interacts with other proteins during the repair process but also coordinates with several repair proteins to enhance the efficiency of DNA repair [12].

While there are over 300 single nucleotide polymorphisms (SNPs) described in XRCC1 gene, only three are frequently studied: the amino acid substitutions at codon 194 (rs1799782), codon 280 (rs25489), and codon 399 (rs25487); these non-conservative amino acid changes may alter XRCC1 function. These three particular SNPs may cause diminished repair kinetic affecting the immune response balance [13] as defects in the repair of DNA double-strand breaks may cause accumulation of genomic alterations and promote apoptosis [14].

XRCC1 Arg399Gln (rs25487) minor allele showed relatively high frequency and is associated with increased risk to SLE. It also confers risk to clinical manifestations of SLE and immunologic disorders [14] as rheumatoid arthritis, systemic sclerosis, ulcerative colitis, multiple sclerosis, and vitiligo [12]. Although previous studies have shown that XRCC1 polymorphisms are associated with several autoimmune diseases, on the other hand, other reports have found no such associations [15].

Therefore, the current research aimed to study the association of XRCC1 Arg399Gln gene polymorphism with SLE and its clinical manifestations.

\section{Methods}

\section{Study design and setting}

This case-control study was conducted in the inpatient and outpatient clinics of Rheumatology and Rehabilitation and Medical Biochemistry and Molecular Biology Departments, Zagazig University Hospitals, between 2017 and 2019.

\section{Study participants}

Ninety subjects were classified into two groups:

Group I (SLE group): Included 45 SLE patients diagnosed according to the 2012 Systemic Lupus International Collaborating Clinics (SLICC) classification criteria for SLE [16]. Patient age above 16 years old with mean age was $34.76 \pm 8.83$ years and sex distribution was as follows: $77.8 \%$ females and $22.2 \%$ males. Patients with other autoimmune diseases; patients with cardiac, chest, and neurological and kidney diseases due to causes other than SLE; and patients with urinary infection were excluded from the study.

Group II (control group): Included 45 apparently healthy controls whose age and sex matched with the case group. Clinical examination as well as routine laboratory investigations confirmed their healthy state.

\section{Sample size and technique}

Sample size was calculated to be 90 individuals as a comprehensive sample and divided into two groups: 45 in the SLE group and 45 as healthy control. The sample calculated as the estimated number of SLE patients fulfilling the inclusion criteria attending to the Rheumatology and Rehabilitation Department during the study period is 120 per year. Simple and systematic random sampling techniques were adopted for the selection of the participants.

\section{Tools and instruments used in data collection}

Data was collected from patient history obtained from medical records of SLE patients having follow-up in our department, complete examination, and investigations.

\section{Operational steps}

- Complete clinical examination including assessment of weight loss [17].

- Activity was assessed by the SLE disease activity index (SLEDAI) [18].

- Severity was assessed by Systemic Lupus International Collaborating Clinics/American College of Rheumatology [SLICC/ACR] Damage Index for SLE [19].

- Laboratory investigations: complete blood picture, fasting blood sugar, erythrocyte sedimentation rate (ESR) [20], C-reactive protein (CRP), C3 and C4 [21], liver function tests [22], kidney function tests [22], creatinine clearance, protein in 24-h urine collection, complete urine analysis, antinuclear antibody (ANA), and anti-double-stranded DNA (antidsDNA) antibody titer.

- Imaging study: plain X-ray on the chest PA view, pelviabdominal ultrasonography.

- Sampling of blood and laboratory assay: venous blood samples were obtained and used as follows: 5 $\mathrm{ml}$ was collected in an ethylene diamine tetra acetate (EDTA) tube for XRCC1 Arg399Glngene polymorphism analysis.

- DNA extraction and genotype analysis (XRCC1 Arg399Gln): DNA was extracted from peripheral leukocytes using a salting out procedure. The presence of the XRCC1 Arg399Gln (rs25487) variant was identified by polymerase chain reactionrestriction fragment length polymorphism (PCRRFLP) [11]. PCR was carried out using primer pair 5' ACCTTGTGCTTTCTCTGTGTC 3' and 5' TAGTCTGCTGG CTCTGGGCT 3'. The PCRamplified fragments $509 \mathrm{bp}$ in length containing the 
XRCC1 Arg399Gln polymorphism were digested with endonuclease NciI (CC/SGG). PCR conditions were $95^{\circ} \mathrm{C}$ for $3 \mathrm{~min}$, followed by 40 cycles of $94{ }^{\circ} \mathrm{C}$ for $30 \mathrm{~s}, 57^{\circ} \mathrm{C}$ for $45 \mathrm{~s}, 72^{\circ} \mathrm{C}$ for $45 \mathrm{~s}$, and a final extension step at $72{ }^{\circ} \mathrm{C}$ for $5 \mathrm{~min}$. XRCC1 $399 \mathrm{Arg}$ allele was cleaved into 387-bp and 137-bp fragments, whereas the XRCC1 399 Gln allele was not cleaved. The DNA fragments were separated according to size by electrophoresis on $2 \%$ agarose gel and observed by ethidium bromide staining (Fig. 1).

\section{Ethics approval and consent to participate}

Official permissions were obtained from the Institutional Review Board at the Faculty of Medicine, Zagazig University Hospitals (ZU-IRB\#3340/13-3-2017) and from the Rheumatology and Rehabilitation and Biochemistry Departments at the same University. The study has been carried out in accordance with The Code of Ethics of the World Medical Association (Declaration of Helsinki 1964) for studies involving humans. A written informed consent was obtained from all participants, and they had the right to withdraw from the study at any time and without negatively affecting their medical care. The results of this study could be used as a scientific publication, but the identity of the participant will be absolutely confidential.

\section{Statistical analysis}

The data were analyzed by the Statistical Package for Social Science (version 20.0. Armonk, NY: IBM Corp). Quantitative variables were expressed as mean \pm

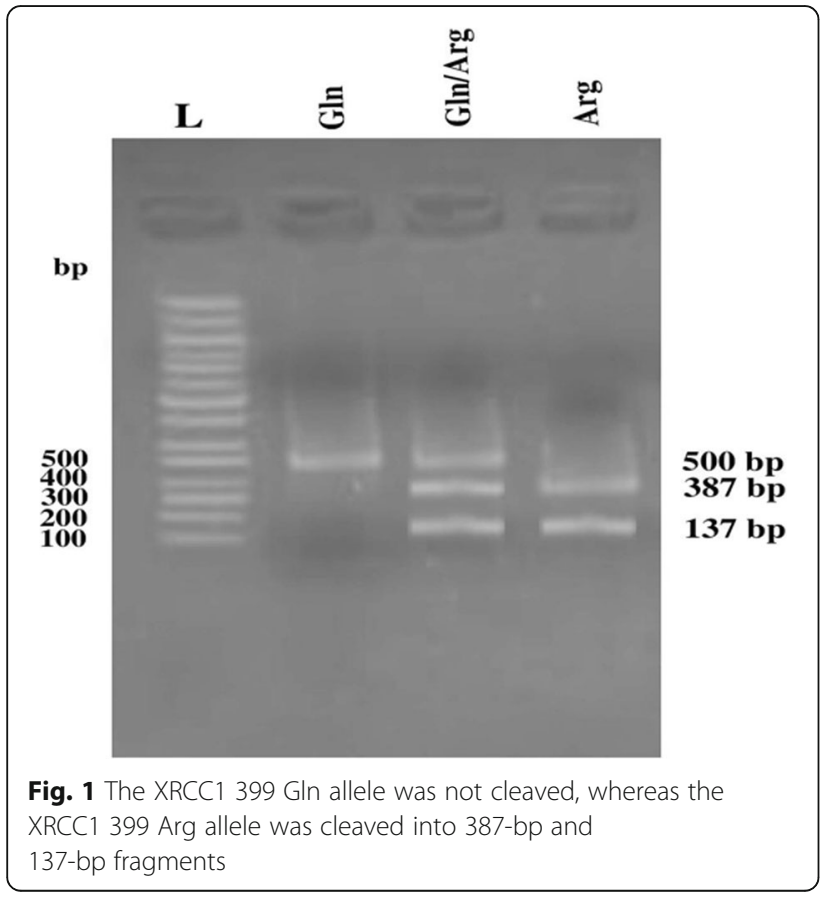

standard deviation (SD) while qualitative variables as number and percentage. A chi-square test was used. The results were considered statistically insignificant and statistically significant when the $P$ value was $>0.05$ and $\leq$ $0.05^{*}$, respectively.

\section{Results}

A total of 90 participants were included in the current study and divided into 45 SLE patients and 45 healthy controls with no statistically significant difference $(P>$ 0.05 ) between them regarding demographic characteristics, ensuring homogeneity of both groups.

There was no significant difference $(P>0.05)$ between both groups regarding genotype and allele frequency. However, regarding genotype and allele frequency of XRCC1 Arg 399 Gln polymorphism, Table 1 shows that genotype AA was more frequent in controls (44.4\%) than in SLE patients (33.4\%), genotype GG was more frequent in SLE patients (22.2\%) than in controls (11.2\%), and genotype AG was equally distributed between both groups with $44.4 \%$ for each of them. Among the SLE patients, the highest proportion of them (44.4\%) had genotype AG followed by genotype AA and genotype GG with $33.4 \%$ and $22.2 \%$, respectively. Also, allele A was more frequent in controls (66.7\%) than in SLE patients (55.6\%) and allele G was more frequent in SLE patients (44.4\%) than controls (33.3\%).

Relation between genotypes and clinical manifestations among the SLE patients showed that there was a significant association $(P \leq 0.05 \%)$ between weight loss and genotype GG, while there was no significant association $(P>0.05)$ between genotypes and all other clinical manifestations. The higher percentage of patients with fever, malar rash, hair falling, photosensitivity, Raynaud's, oral/ nasal ulcers, discoid lesion, arthritis/arthralgia, myositis, avascular necrosis, pulmonary, neurologic, GIT, visual manifestations, hypertension, lymphadenopathy, and lower limb edema had genotype AG; on the other hand, the higher percentage of patients with skin rash and

Table 1 Genotype and allele frequency of XRCC1 Arg 399 Gln polymorphism among the studied participants $(n=90)$

\begin{tabular}{|c|c|c|c|c|}
\hline & $\begin{array}{l}\text { SLE patients }(\boldsymbol{n}=45) \\
\text { No. }(\%)\end{array}$ & $\begin{array}{l}\text { Controls }(\boldsymbol{n}=45) \\
\text { No. }(\%)\end{array}$ & ${ }^{a} x^{2}$ & $\boldsymbol{P}$ value \\
\hline \multicolumn{5}{|c|}{ Genotypes } \\
\hline AA & 15 (33.4\%) & $20(44.4 \%)$ & 2.381 & 0.304 \\
\hline GG & 10 (22.2\%) & $5(11.2 \%)$ & & \\
\hline AG & $20(44.4 \%)$ & $20(44.4 \%)$ & & \\
\hline \multicolumn{5}{|c|}{ Alleles } \\
\hline A & $50(55.6 \%)$ & 60 (66.7\%) & 2.238 & 0.126 \\
\hline G & 40 (44.4\%) & 30 (33.3\%) & & \\
\hline
\end{tabular}

${ }^{a}$ Chi-square test $\left(X^{2}\right)$. SLE systemic lupus erythematosus. $P>0.05$ : insignificant, $P \leq 0.05$ : significant 
cardiac manifestations had genotype AA and the higher percentage of patients with weight loss and subcutaneous nodule had genotype GG (Table 2).

Among the SLE patients, there was a statistically significant association $\left(P \leq 0.05^{*}\right)$ between high serum creatinine, low C3 level, and genotype AG. However, there was no statistically significant association $(P>0.05)$ between genotypes and all other laboratory and immunological parameters (Table 3).

Table 4 shows that there was no statistically significant association $(P>0.05)$ between genotypes and SLEDAI score among the SLE patients; however, the percent of very high activity score was higher with genotype AG $(40 \%)$, and also no significant association $(P>0.05)$ was found between genotypes and SLICC/ACR Damage Index score; however, the percent of more severe score was higher with genotype AG (47.6\%).

\section{Discussion}

It has been reported that DNA repair is declined in SLE patients. Leucocytes from these patients exhibited raised levels of spontaneous single-strand breaks and aggregation of oxidative DNA lesions as compared to those from healthy individuals. Moreover, SLE lymphocytes subjected to -radiation or SLE neutrophils with oxidative DNA damages may present reduced ability of DNA repair [23].

The study at hand showed that there was no significant difference between SLE patients and control groups regarding genotype frequency of XRCC1 Arg 399 Gln polymorphism; however, genotype AA was more frequent in controls (44.4\%) than in SLE patients (33.4\%), genotype GG was more frequent in SLE patients (22.2\%) than in controls (11.2\%), and genotype AG was equally distributed between both groups with $44.4 \%$ for each of them. The highest proportion of SLE patients (44.4\%) had genotype AG followed by genotype AA and genotype GG with $33.4 \%$ and $22.2 \%$, respectively.

In agreement with the study carried out by Warchol et al., it was found that there was no significant difference between the control group and SLE patients regarding XRCC1 Arg 399 Gln polymorphism among the Polish population. However, the frequency of the XRCC1 399 Gln/Gln genotype and 399 Gln/Arg

Table 2 XRCC1 Arg 399 Gln polymorphism with clinical manifestations among SLE patients ( $n=45)$

\begin{tabular}{|c|c|c|c|c|c|}
\hline Manifestations & $\begin{array}{l}\text { Genotype AA }(\boldsymbol{n}=15) \\
\text { No. }(\%)\end{array}$ & $\begin{array}{l}\text { Genotype GG }(\boldsymbol{n}=10) \\
\text { No. (\%) }\end{array}$ & $\begin{array}{l}\text { Genotype AG }(\boldsymbol{n}=20) \\
\text { No. (\%) }\end{array}$ & ${ }^{\mathrm{a}} X^{2}$ & $\boldsymbol{P}$ value \\
\hline Weight loss $(n=13)$ & $3(23.1 \%)$ & $6(46.1 \%)$ & $4(30.8 \%)$ & 6.05 & $0.048^{*}$ \\
\hline Fatigue $(n=11)$ & $4(36.4 \%)$ & $4(36.4 \%)$ & $3(27.2 \%)$ & 2.32 & 0.314 \\
\hline Fever $(n=25)$ & $8(32 \%)$ & $6(24 \%)$ & $11(44 \%)$ & 0.11 & 0.954 \\
\hline Malar rash $(n=36)$ & $13(36.1 \%)$ & $8(22.2 \%)$ & $15(41.7 \%)$ & 0.73 & 0.694 \\
\hline Hair falling $(n=37)$ & $11(29.7 \%)$ & $7(19 \%)$ & $19(51.3 \%)$ & 4.07 & 0.131 \\
\hline Photosensitivity $(n=35)$ & $12(34.3 \%)$ & $6(17.1 \%)$ & $17(48.6 \%)$ & 2.48 & 0.290 \\
\hline Skin rash $(n=16)$ & $7(43.8 \%)$ & $3(18.7 \%)$ & $6(37.5 \%)$ & 1.21 & 0.545 \\
\hline Vasculitis ( $n=12$ ) & $5(41.7 \%)$ & $5(41.7 \%)$ & $2(16.6 \%)$ & 5.97 & 0.051 \\
\hline Raynaud's $(n=19)$ & $6(31.6 \%)$ & $5(26.3 \%)$ & $8(42.1 \%)$ & 0.31 & 0.853 \\
\hline S.C nodule $(n=1)$ & $0.0(00 \%)$ & $1(100 \%)$ & $0.0(00 \%)$ & 3.58 & 0.167 \\
\hline Oral/nasal ulcers $(n=25)$ & $9(36 \%)$ & $3(12 \%)$ & $13(52 \%)$ & 3.49 & 0.175 \\
\hline Discoid lesion $(n=5)$ & $2(40 \%)$ & $0.0(00 \%)$ & $3(60 \%)$ & 1.63 & 0.442 \\
\hline Arthritis/arthralgia $(n=41)$ & $13(31.7 \%)$ & $10(24.4 \%)$ & $18(43.9 \%)$ & 1.37 & 0.504 \\
\hline Myositis $(n=4)$ & $1(25 \%)$ & $1(25 \%)$ & $2(50 \%)$ & 0.13 & 0.934 \\
\hline Avascular necrosis $(n=17)$ & $6(35.3 \%)$ & $2(11.8 \%)$ & $9(52.9 \%)$ & 1.82 & 0.403 \\
\hline Cardiac $(n=17)$ & $8(47.1 \%)$ & $4(23.5 \%)$ & $5(29.4 \%)$ & 2.95 & 0.228 \\
\hline Pulmonary $(n=16)$ & $5(31.2 \%)$ & $3(18.8 \%)$ & $8(50 \%)$ & 0.33 & 0.844 \\
\hline Neurologic $(n=28)$ & $8(28.6 \%)$ & $3(18.8 \%)$ & $13(46.4 \%)$ & 0.82 & 0.661 \\
\hline GIT $(n=9)$ & $1(33.3 \%)$ & $3(22.2 \%)$ & $5(44.5 \%)$ & 2.60 & 0.272 \\
\hline Visual $(n=15)$ & $5(33.3 \%)$ & $2(13.3 \%)$ & $8(53.4 \%)$ & 1.20 & 0.549 \\
\hline Hypertension $(n=26)$ & $9(34.6 \%)$ & $6(23.1 \%)$ & $11(42.3 \%)$ & 0.11 & 0.945 \\
\hline Lymphadenopathy $(n=15)$ & $4(26.7 \%)$ & $5(33.3 \%)$ & $6(40 \%)$ & 1.65 & 0.438 \\
\hline Lower limb edema $(n=27)$ & $10(37.1 \%)$ & 5 (18.5\%) & $12(44.4 \%)$ & 0.69 & 0.707 \\
\hline
\end{tabular}

${ }^{a}$ Chi square test $\left(X^{2}\right)$. SLE systemic lupus erythematosus, SC subcutaneous, GIT gastrointestinal tract. $P>0.05$ : insignificant, $P \leq 0.05$ : significant 
Table 3 XRCC1 Arg 399 Gln polymorphism with laboratory and immunological parameters among SLE patients $(n=45)$

\begin{tabular}{|c|c|c|c|c|c|}
\hline Parameters & $\begin{array}{l}\text { Genotype AA }(\boldsymbol{n}=15) \\
\text { No. }(\%)\end{array}$ & $\begin{array}{l}\text { Genotype GG }(\boldsymbol{n}=10) \\
\text { No. }(\%)\end{array}$ & $\begin{array}{l}\text { Genotype AG }(\boldsymbol{n}=20) \\
\text { No. (\%) }\end{array}$ & ${ }^{\mathrm{a}} x^{2}$ & $\boldsymbol{P}$ value \\
\hline Leucopenia $(n=18)$ & $5(27.8 \%)$ & $4(22.2 \%)$ & $9(50 \%)$ & 0.49 & 0.784 \\
\hline Anemia $(n=24)$ & $6(25 \%)$ & $5(20.8 \%)$ & $13(54.2 \%)$ & 2.21 & 0.331 \\
\hline Thrombocytopenia $(n=2)$ & $1(50 \%)$ & $1(50 \%)$ & $0.0(00 \%)$ & 1.83 & 0.400 \\
\hline High ESR $(n=44)$ & $15(34.1 \%)$ & $9(20.4 \%)$ & $20(45.5 \%)$ & 3.58 & 0.167 \\
\hline High CRP $(n=27)$ & $9(33.3 \%)$ & $7(26 \%)$ & $11(40.7 \%)$ & 0.63 & 0.732 \\
\hline High FBG $(n=2)$ & $0.0(00 \%)$ & $1(50 \%)$ & $1(50 \%)$ & 1.44 & 0.487 \\
\hline High BUN $(n=19)$ & $9(47.4 \%)$ & $4(21 \%)$ & $6(31.6 \%)$ & 3.19 & 0.203 \\
\hline High serum creatinine $(n=21)$ & 7 (33.3\%) & $3(14.3 \%)$ & $11(52.4 \%)$ & 6.50 & $0.039 *$ \\
\hline Low creatinine clearance $(n=19)$ & $8(42.1 \%)$ & $4(21.1 \%)$ & $7(36.8 \%)$ & 1.21 & 0.547 \\
\hline Low serum albumin $(n=39)$ & $13(33.3 \%)$ & $8(20.5 \%)$ & $18(46.2 \%)$ & 0.58 & 0.749 \\
\hline High serum ALT $(n=10)$ & $1(10 \%)$ & $3(30 \%)$ & $6(60 \%)$ & 3.15 & 0.207 \\
\hline High serum AST $(n=11)$ & $2(18.2 \%)$ & $2(18.2 \%)$ & $7(63.6 \%)$ & 2.34 & 0.314 \\
\hline Urinary albumin $(n=34)$ & $13(38.2 \%)$ & $8(23.6 \%)$ & $13(38.2 \%)$ & 2.32 & 0.314 \\
\hline Pyuria $(n=26)$ & $9(34.6 \%)$ & $7(26.9 \%)$ & $10(38.5 \%)$ & 1.14 & 0.566 \\
\hline Hematuria $(n=18)$ & $9(50 \%)$ & $3(16.7 \%)$ & $6(33.3 \%)$ & 3.75 & 0.153 \\
\hline Cast $(n=10)$ & $4(40 \%)$ & $1(10 \%)$ & $5(50 \%)$ & 1.13 & 0.570 \\
\hline Proteinuria $(n=33)$ & $12(36.4 \%)$ & $7(21.2 \%)$ & $14(42.4 \%)$ & 0.51 & 0.774 \\
\hline Low C3 level $(n=30)$ & $9(30 \%)$ & $10(33.3 \%)$ & $11(36.7 \%)$ & 9.53 & $0.009 *$ \\
\hline Low C4 level ( $n=23)$ & $8(34.8 \%)$ & $7(30.4 \%)$ & $8(34.8 \%)$ & 2.45 & 0.294 \\
\hline Positive ANA $(n=43)$ & $14(32.5 \%)$ & $10(23.3 \%)$ & $19(44.2 \%)$ & 0.65 & 0.721 \\
\hline Positive anti-dsDNA $(n=25)$ & $9(36 \%)$ & $5(20 \%)$ & $11(44 \%)$ & 0.25 & 0.884 \\
\hline
\end{tabular}

${ }^{a}$ Chi-square test $\left(X^{2}\right)$. SLE systemic lupus erythematosus, $C B C$ complete blood picture, ESR erythrocyte sedimentation rate, CRP C-reactive protein, $F B G$ fasting blood sugar, BUN blood urea nitrogen, ALT alanine aminotransferase, AST aspartate aminotransferase, ANA antinuclear antibody, anti-dsDNA anti-double-stranded DNA. $P$ $>0.05$ : insignificant, $P \leq 0.05$ : significant

heterozygous were higher in SLE patients. They also found that the highest percentage of SLE patients had genotype AG then genotype AA and finally genotype GG [13].

Also, Bassi et al., who studied Brazilian populations [24], Cristhiane et al. [8], and Peng et al. [12] did not confirm the association between SLE development and XRCC1 Arg399Gln polymorphism.
In contrast with the study conducted by Lin et al., among Taiwanese Han Chinese population revealed the involvement of Arg/Gln polymorphism at codon 399 in the pathogenesis of SLE. The Arg/Gln genotype had a higher risk for developing SLE disease [25].

However, Salimi et al. demonstrated that SLE risk was lower in individuals with Arg/Gln and Gln/Gln genotypes compared with those with Arg/Arg genotype. So,

Table 4 XRCC1 Arg 399 GIn polymorphism with SLEDAI and SLICC/ACR Damage Index among SLE patients $(n=45)$

\begin{tabular}{|c|c|c|c|c|c|}
\hline & $\begin{array}{l}\text { Genotype AA }(\boldsymbol{n}=15) \\
\text { No. }(\%)\end{array}$ & $\begin{array}{l}\text { Genotype GG }(\boldsymbol{n}=10) \\
\text { No. }(\%)\end{array}$ & $\begin{array}{l}\text { Genotype AG }(\boldsymbol{n}=20) \\
\text { No. }(\%)\end{array}$ & ${ }^{\mathrm{a}} x^{2}$ & $\boldsymbol{P}$ value \\
\hline \multicolumn{6}{|l|}{ SLEDAI } \\
\hline Inactive $(n=1)$ & $1(100 \%)$ & $0.0(00 \%)$ & $0.0(00 \%)$ & 3.45 & 0.902 \\
\hline Mild activity $(n=6)$ & $2(33.3 \%)$ & $1(16.7 \%)$ & $3(50 \%)$ & & \\
\hline Moderate activity $(n=4)$ & $1(25 \%)$ & $1(25 \%)$ & $2(50 \%)$ & & \\
\hline High activity $(n=14)$ & $5(35.7 \%)$ & $2(14.3 \%)$ & $7(50 \%)$ & & \\
\hline Very high $(n=20)$ & $6(30 \%)$ & $6(30 \%)$ & $8(40 \%)$ & & \\
\hline \multicolumn{6}{|l|}{ SLICC/ACR Damage Index } \\
\hline Less severe $\leq$ median(4) $(n=24)$ & $9(37.5 \%)$ & $5(20.8 \%)$ & $10(41.7 \%)$ & 4.69 & 0.096 \\
\hline More severe $>$ median( $(4)(n=21)$ & $6(28.6 \%)$ & $5(23.8 \%)$ & $10(47.6 \%)$ & & \\
\hline
\end{tabular}

${ }^{a}$ Chi-square test $\left(X^{2}\right)$. SLE systemic lupus erythematosus, SLEDA/ SLE disease activity index, SLICC/ACR Systemic Lupus International Collaborating Clinics/American College of Rheumatology. $P>0.05$ : insignificant, $P \leq 0.05$ : significant 
Arg/Gln genotype is a protective factor in SLE susceptibility. In their study, the highest proportion of SLE patients had genotype AA followed by genotype AG then genotype GG as AA genotype is risky [10].

In addition, we found that there was no significant difference between both groups regarding allele frequency of XRCC1 Arg 399 Gln polymorphism; however, allele A was more frequent in controls than in SLE patients and allele $\mathrm{G}$ was more frequent in SLE patients than in controls. As regards allele frequency in SLE patients, we found that the highest proportion of SLE patients had allele A then allele $\mathrm{G}$.

Similarly, Lin et al. [25] and Bassi et al. [24] showed that allelic frequency analyses did not reveal a difference at codon 399 between the patients and controls.

But Warchol et al. found a significantly higher frequency of the XRCC1 399 Gln allele in SLE patients, indicating that allele Gln was risky. They also mentioned that $92.8 \%$ of SLE patients had allele A then allele G with $7.2 \%$ [13].

In contrast, Salimi et al. [10] and Cristhiane et al. [8] demonstrated that the frequency of Gln allele was significantly lower in the SLE group indicating that Gln allele is a protective factor in SLE susceptibility.

In the current study, we found a significant association between weight loss and genotype GG. But, there was no significant association between genotypes of XRCC1 Arg 399 Gln polymorphism and demographic characteristics, disease duration, and other clinical manifestations among the SLE patients. This association of weight loss with genotype GG can be explained by SLE patients who are suffering from loss of appetite and weight loss and this reduce consumption of healthy foods that help to maintain DNA integrity.

In difference with the result of Warchol et al., it was shown that there was a significant contribution of the Gln/Gln or Arg/Gln versus Arg/Arg genotype to the presence of malar rash or photosensitivity manifestations [13].

Lin et al. revealed an association between the XRCC1 Arg/Gln heterozygotes and photosensitivity or malar rash in SLE patients from the Taiwanese Han Chinese population that related to the reduced ability to counteract UV irradiation implying the important functions of XRCC1 SNPs in SLE development. Furthermore, in this population, the XRCC1 Arg/Gln heterozygote has also been associated with hematologic and arthritis manifestations and the presence of ANA [25].

Meanwhile, Salimi et al. mentioned that lower frequency of $\mathrm{Arg} / \mathrm{Gln}$ genotype is observed in patients with malar rash compared to patients without this feature. Moreover, no association was found between XRCC1 polymorphisms and other SLE manifestations [10].

As regards investigations, we found that there was a significant association between Arg/Gln genotypes and low C3 level and high serum creatinine. However, there was no statistically significant association between genotypes and other immunologic and laboratory results.

This may be explained by Radwan et al., who demonstrated that XRCC1 Arg399Gln polymorphism may contribute to individual susceptibility to end-stage renal disease among the Egyptian population [26].

In addition, Warchol et al. found that there was no contribution of the XRCC1 Arg399Gln polymorphism to the presence of anti-dsDNA Abs or ANA [13].

But Bassi et al. [24] observed the association of XRCC1 $\mathrm{Gln} / \mathrm{Gln}$ or $\mathrm{Arg} / \mathrm{Gln}$ genotypes with the presence of anti-dsDNA Ab, and Lin et al. reported that the XRCC1 $\mathrm{Arg} / \mathrm{Gln}$ heterozygote has been associated with the presence of ANA. These results indicated that in patients with 399Gln polymorphism, breaks in DNA mixed with nuclear proteins were strong immunogens for eliciting auto-reactive antibodies (Abs) in patients with SLE [25].

In the present study, there was no significant association between genotypes and SLEDAI score; however, the percent of very high activity score was higher among the SLE patients with genotype Arg/Gln.

Also, Warchol et al. did not find statistically significant differences in SLEDAI between XRCC1 Arg399Gln genotype groups [13].

In addition, the study at hand showed that no statistically significant association was found between genotypes and SLICC/ACR Damage Index score, but the percent of inadequate score was higher among the SLE patients with genotype Arg/Gln.

A recent meta-analysis study showed no significant association of XRCC1 Arg399Gln polymorphism with SLE in all genetic models when all study subjects were considered together. After stratification by ethnicity, they observed a significant association between the Arg399Gln polymorphism and SLE in Asians and Caucasians. These findings suggested that the Arg399 allele may be a risk factor for SLE in Asians, while the Arg399 allele may be a protecting factor for SLE in Caucasians. So, $G$ allele is a risk factor for SLE among Caucasians [11].

These variations in the effect of the XRCC1 Arg399Gln genotypes on the susceptibility of SLE and clinical manifestations in different ethnicities may be explained by the sample size of the studied groups or racial heterogeneity $[27,28]$.

This discrimination may also be caused by different populations' exposure to diverse environmental chemicals interacting with the XRCC1 Arg399Gln genotypes. This eventually may induce different influences on the SLE risk incidence among the studied ethnicities such as autoimmune diseases that are complex and multifactorial, resulted from the genetic interaction and environmental factors [11]. 
So far, the XRCC1 399 Gln polymorphic variant has also been recognized as a genetic modifier for raising the formation of DNA adducts and DNA damage in individuals exposed to aflatoxin B1, cigarette smoke, 1,3-butadiene, vinyl chloride metabolites, or styrene [29-33].

This study had some limitations that included relatively small sample size and single place and the data could not be generalized as the study design was institutional based and not community based. Another limitation of the present study was that the environmental exposure to various injurious agents such as excessive sun exposure, smoking, chemicals, and insecticides was not studied in our study population.

\section{Conclusion}

The present study showed that there was an association between weight loss, high serum creatinine, and low C3 level and genotypes. However, there was no association between genotypes (AA, GG, or AG) and allele frequency of XRCC1 Arg 399 Gln polymorphism and SLE susceptibility. Further research is required to investigate if XRCC1 Arg 399 Gln polymorphism is related to the pattern of renal affection in lupus. Also, a large-scale genome-wide association study (GWAS) on the national level for patients with SLE as a model of one of the most disabling and severe rheumatic multisystem disorders is recommended. The study of the genetic profile of SLE patients is recommended to identify those who are most at risk for organ damage for more close follow-up and tight disease control.

\section{Abbreviations \\ ANA: Antinuclear antibody; Anti-dsDNA: Anti-double stranded DNA; CRP: C- reactive protein; DNA: Deoxyribonucleic acid; EDTA: Ethylene diamine tetra acetate; ESR: Erythrocyte sedimentation rate; GWAS: Large-scale genome- wide association study; PCR-RFLP: Polymerase chain reaction-restriction fragment length polymorphism; SD: Standard deviation; SLE: Systemic lupus erythematosus; SLEDAI: SLE disease activity index; SLICC/ACR: Systemic Lupus International Collaborating Clinics/American College of Rheumatology; SLICC: Systemic Lupus International Collaborating Clinics; SNPs: Single nucleotide polymorphisms \\ Acknowledgements \\ The authors thank all staff members and colleagues in the Rheumatology and Rehabilitation and Medical Biochemistry and Molecular Biology Departments, Zagazig University Hospitals, Egypt, for their helpful cooperation and all the study participants for their patience and support.}

\section{Authors' contributions}

MM designed the work and shared in the drafting of the article. $\mathrm{HZ}$ contributed to the acquisition of the data and shared in the drafting of the article. NA contributed to the analysis and interpretation of the data and shared in the drafting of the article. ME shared in the drafting of the article and substantively revised it. All authors have read and approved the final manuscript.

\section{Funding}

The authors declare that they have no funding support.

Availability of data and materials

Not applicable

\section{Ethics approval and consent to participate}

Official permissions were obtained from Institutional Review Board at Faculty of Medicine, Zagazig University Hospitals (ZU-IRB\#3340/13-3-2017), and from the Rheumatology and Rehabilitation and Biochemistry Departments at the same University. The study has been carried out in accordance with The Code of Ethics of the World Medical Association (Declaration of Helsinki 1964) for studies involving humans. A written informed consent was obtained from all participants, and they had the right to withdraw from the study at any time and without negatively affecting their medical care. The results of this study could be used as a scientific publication, but the identity of the participant will be absolutely confidential.

\section{Consent for publication}

A written informed consent was voluntarily sought from the participants.

\section{Competing interests}

The authors declare that they have no competing interests.

\section{Author details}

${ }^{1}$ Rheumatology and Rehabilitation Department, Faculty of Medicine, Zagazig University, Zagazig, Egypt. ${ }^{2}$ Medical Biochemistry and Molecular Biology

Department, Faculty of Medicine, Zagazig University, Zagazig, Egypt.

Received: 25 March 2020 Accepted: 18 May 2020

Published online: 01 September 2020

\section{References}

1. Fettouh DS, Saif DS, El Gazzar SF, Sonbol AA (2019) Study the relationship between vitamin A deficiency, T helper17, regulatory $T$ cells, and disease activity in patients with systemic lupus erythematosus. Egyp Rheumatol Rehabil 46:244-250

2. Mohamed AAA, Gheita TA (2018) Interferons, B cells and neutrophils: innate and adaptive allies in systemic lupus erythematosus. J Rheumatol Arthritic Dis 3(2):1-12. https://doi.org/10.15226/2475-4676/3/2/00136

3. Goulielmos GN, Zervou MI, Vazgiourakis VM (2018) The genetics and molecular pathogenesis of systemic lupus erythematosus (SLE) in populations of different ancestry. Gene 668:59-72

4. Almousa S, Ahmad T, Hamdan S, Katt N (2020) Lupus erythematosustumidus (LET) with autoimmune thyroid dysfunction (AITD) as the first presentation of systemic lupus erythematosus: a case report and review of the literature. Egyp Rheumatol. https://doi.org/10.1016/j.ejr.2020. 02.002

5. Nasr AS, Darweesh H, El Khateeb E, Fayed HL, El-Dakrony A (2017) Role of glutathione S-transferases polymorphisms and monocyte CD64 expression in Egyptian patients with systemic lupus erythematosus. Egyp Rheumatol. https://doi.org/10.1016/j.ejr.2017.04.001

6. Harraz E, Hammad E, Darwish M, Awad M, Salah S, Farag SE (2016) Mannose binding lectin 2 promotor-221 X/Y gene polymorphism in Egyptian systemic lupus erythematosus patients. Egypt Rheumatol 38:301-306

7. Rose T, Dörner T (2017) Drivers of the immunopathogenesis in systemic lupus erythematosus. Best Pract Res Clin Rheumatol 31(3):321-333

8. Leite Da Silva CA, Galera MF, Festi RR, Espinosa MM, Fernandes V, Blaskievicz $\mathrm{PH}$ et al (2019) Association of polymorphisms in the DNA repair genes XRCC1 and XRCC3 with systemic lupus erythematosus. Open Rheumatol J 13:15-21

9. Ali A, Sayyed Z, Ameer MA, Arif AW, Kiran FNU, Iftikhar A et al (2018) Systemic lupus erythematosus: an overview of the disease pathology and its management. Cureus 10(9):e3288. https://doi.org/10.7759/cureus.3288

10. Salimi S, Mohammadoo M, Tabatabai E, Sandoughi M, Zakeri Z, Naghavi A (2014) XRCC1 Arg399GIn and Arg194Trp polymorphisms and risk of systemic lupus erythematosus in an Iranian population: a pilot study. Biomed Res Int 492956:5

11. Zhang MY, Yang XK, Ly TT, Wu J, Xu SZ, Wang JB et al (2018) Meta-analysis of associations between XRCC1 gene polymorphisms and susceptibility to systemic lupus erythematosus and rheumatoid arthritis. Int J Rheum Dis 21(1):179-184. https://doi.org/10.1111/1756-185X.12966

12. Peng M, Zhou X, Ding X, Wei L, Zhao Y, Tao Zhu T et al (2017) Association of XRCC1 Arg399GIn and Arg194Trp polymorphisms with susceptibility to multiple autoimmune diseases: a meta-analysis. Rheumatol Int 37:435-444 
13. Warchoł T, Mostowska A, Lianeri M, Lącki JK, Jagodziński PP (2012) XRCC1 arg399gln gene polymorphism and the risk of systemic lupus erythematosus in the polish population. DNA Cell Biol 31:50-56

14. De Azevêdo SJ, Addobbati C, Sandrin-Garcia P, Crovella S (2014) Systemic lupus erythematosus: old and new susceptibility genes versus clinical manifestations. Curr Genom 15:52-65

15. Mohamed RH, El-Shal A, El-Shahawy EE, Abdel Galil SM (2016) Association of XRCC1 and OGG1 DNA repair gene polymorphisms with rheumatoid arthritis in Egyptian patients. Gene 578(1):112-116. https:/doi.org/10.1016/j.gene.2015.12.021

16. Petri M (2012) Systemic Lupus International Collaborating Clinics (SLICC) Revision of the ACR classification criteria for systemic lupus erythematosus. Arthritis Rheum 60(10):895

17. Omnibus Reconciliation Act (OBRA) (1987) Involuntary weight loss and protein-energy malnutrition: Diagnosis and Treatment. Available from: https://www.medscape.org. Accessed: 5 July 2019

18. Gladman DD, Ibanez D, Urowitz MB (2002) Systemic lupus erythematosus disease activity index. J Rheumatol 29:288-291

19. Gladman DD, Urowitz MB, Goldsmith CH, Fortin P, Ginzler E, Gordon C et al (1997) The reliability of the Systemic Lupus International Collaborating Clinics/American College of Rheumatology Damage Index in patients with systemic lupus erythematosus. Arthritis Rheum 40(5):809-813

20. Westergern N (1957) Estimation of ESR. Triangle (EN) 3:20

21. Barnes EV, Narain S, Naranjo A, Hebert LA, Rovin BH (2005) High sensitivity C reactive protein in systemic lupus erythematosus: relation to disease activity, clinical presentation and implication for cardiovascular risk. Lupus 14:576-582

22. Department of Health and Human Services (1992) Clinical laboratory improvement amendments. Fed Regist 57:7002-7186

23. Chen YT, Chen SY, Lin YJ, Huang CM, Chang YY, Tsai FJ (2014) Association between XRCC3 Thr241Met SNP and systemic lupus erythematosus in Han Chinese patients in Taiwan, and a meta-analysis of healthy populations. I Clin Lab Anal 28(2):118-123

24. Bassi C, Dj X, Palomino G, Nicolucci P, Soares C, Sakamoto-Hojo E et al (2008) Efficiency of the DNA repair and polymorphisms of the XRCC1, XRCC3 and XRCC4 DNA repair genes in systemic lupus erythematosus. Lupus 17:988-995. https://doi.org/10.1177/0961203308093461

25. Lin YJ, Wan L, Huang CM, Chen SY, Huang YC, Lai CH et al (2009) Polymorphisms in the DNA repair gene XRCC1 and associations with systemic lupus erythematosus risk in the Taiwanese Han Chinese population. Lupus 18:1246-1251

26. Radwan W, Elbarbary H, Alsheikh N (2015) DNA repair genes XPD and XRCC1 polymorphisms and risk of end-stage renal disease in Egyptian population. Ren Fail 37(1):122-128

27. Sarzi-Puttini P, Atzeni F, laccarino L, Doria A (2005) Environment and systemic lupus erythematosus: an overview. Autoimmunity 38:465-462

28. Jonsen A, Bengtsson AA, Nived O, Truedsson L, Sturfelt G (2007) Geneenvironment interactions in the etiology of systemic lupus erythematosus. Autoimmunity 40:613-617

29. Abdel-Rahman S, Soliman AS, Bondy ML, Omar S, El-Badawy SA, Khaled HM et al (2000) Inheritance of the 194Trp and the 399GIn variant alleles of the DNA repair gene XRCC1 are associated with increased risk of early-onset colorectal carcinoma in Egypt. Cancer Lett 159:79-86

30. Godderis L, De Boeck M, Haufroid V, Emmery M, Mateuca R, Gardinal S et al (2004) Influence of genetic polymorphisms on biomarkers of exposure and genotoxic effects in styrene-exposed workers. Environ Mol Mutagen 44:293-303

31. Li Y, Long C, Lin G, Marion MJ, Freyer G, Santella RM et al (2009) Effect of the XRCC1 codon 399 polymorphism on the repair of vinyl chloride metabolite-induced DNA damage. J Carcinog 8:14

32. Wang Q, Wang AH, Tan HS, Feng NN, Ye YJ, Feng XQ et al (2010) Genetic polymorphisms of DNA repair genes and chromosomal damage in workers exposed to 1, 3-butadiene. Carcinogenesis 31:858-863

33. Weng H, Weng Z, Lu Y, Nakayama K, Morimoto K (2009) Effects of cigarette smoking, XRCC1 genetic polymorphisms, and age on basal DNA damage in human blood mononuclear cells. MutatRes 679:59-64

\section{Publisher's Note}

Springer Nature remains neutral with regard to jurisdictional claims in published maps and institutional affiliations.

\section{Submit your manuscript to a SpringerOpen ${ }^{\circ}$ journal and benefit from:}

- Convenient online submission

- Rigorous peer review

- Open access: articles freely available online

High visibility within the field

- Retaining the copyright to your article

Submit your next manuscript at $\boldsymbol{\nabla}$ springeropen.com 